\title{
Sustainable Cultural Development: The Future Of Balinesse Adat Village Posterior The Enactment Of Law Number 6 Year 2014 Concerning Village
}

\author{
I Nyoman Nurjaya ${ }^{1}$ \\ Fakultas Hukum Universitas Brawijaya, \\ Jl. Veteran, Malang, Jawa Timur 65145, \\ Telp. +62 0341-551611, Fax. +62 0341-565420 \\ Email:nurjayai@yahoo.com
}

\begin{abstract}
ABSTRAK
This study aims to find out the sustainable cultural development: the future of balinese adat village posterior the enactment of law number 6 year 2014 concerning village. This research is done empirically juridically, that is by collecting data by researching and examining legal implications posterior the enactment of Law Number 6 of 2014 regarding Village. In the sense of Explanation Article 6 Act Number 6 Year 2014 that stating: "This provision is intended to prevent the intersection in regions in term of authority, institutional duplication between Desa and Desa Adat within the same region, In contradiction, in case the Balinese and the Bali regional government as well is intended to chose the desa adat/desa pakraman to be registered with the hope to the only receive a village financial empowerment every year from the Government, should personally advice that there will be a number of legal consequences with the fate and future of existence and the life of desa adat/desa pakraman as a social and cultural system of Balinese Hindu community in particular and the whole traditional adat communities in the multicultural country of Indonesia in general.
\end{abstract}

Keyword : Suistainable, Cultural, Balinese adat village

\section{A. INTRODUCTION}

Indonesia has been well-known as a multicultural country having many ethnics, religions, religions, races, and classed within. Its official motto: "Unity in Diversity" (Bhinneka Tunggal Ika) - de facto - reflects the cultural plurality within a unitary State of the Republic of Indonesia.

1 Dosen Fakultas Hukum Universitas Brawijaya. 
The region of the country that stretches from Sabang to Merauke has a rich natural resources that overflows as emeralds string in the span of the equator, as well as various cultural resources. ${ }^{1}$

The cultural diversity is in one side a configuration culture that indicating cultural identity of the nation, and empirically it becomes the main element that established the Unitary State of Indonesia. On the other side, the diversity of cultures also becomes a cultural capital and cultural power that driving the dynamic of its national life. However, the cultural diversity is also potential for the emerge of conflicts that can be threatening the national integrity, because the conflict among culture expressed in the form of clashes among ethnics, adherents of the religion, among races and classes is very sensitive and vulnerable to a condition directing the national disintegration. It would be very likely to happen when the conflict is not managed, understood, and resolved in polite way, peaceful, and wise manner by the government together with all components of the nation. ${ }^{2}$

One of the Indonesia's cultural richness namely traditional adat village that is form of social alignment in particular within traditional community's social system include its customary adat law (written or unwritten), an instrument of social control in the life of adat community. The traditional adat villages in the country has been known as desa/dusun in Jawa, desa/banjar pakraman in Bali, nagari in West Sumatra, Gampong in Aceh, marga in Sumatera Selatan, lembang di Toraja, banua/wanua di Kalimantan Barat, negeri di in South Sumatra, tiuh/pekon in Lampung, kadamangan in Central Kalimantan, or huta/nagori in North Sumatera Utara, etc. The terms of

\footnotetext{
1 I Nyoman Nurjaya (2008), Pengelolaan Sumber Daya Alam dalam Perspektif Antropologi Hukum, Prestasi Pustaka Publisher, Jakarta.

2 I Nyoman Nurjaya, "Reorientasi Paradigma Pembangunan Hukum Nasional dalam Masyarakat MultiKultural: Perspektif
}

written indegenous law are awig-awig in Bali dan Lombok, pepakem in Cirebon, kitab simbur cahaya in Lampung, etc.

In the context of national life, traditional adat villages that have existed long period of time should be admitted as the element forming the Unitary State of Indonesia (Negara Kesatuan Republik Indonesia/NKRI). NKRI as a sovereign and independent state formed on the basis of the social structures of indegenous peoples, and a social structure of adat community that grow and develop in the inner life of their community and the adat law.

The paper attempt to outline holistic understanding on the characteristics of of adat community and criterias of adat village, the legal status of adat village in the Indonesia's Constitutional system, recognition and protection of their existence in the 1945 Constitution and the laws, as well as the legal implications posterior the enactment of Law Number 6 of 2014 regarding Village.

\section{B. ANALYSIS AND DISCUSSION}

\section{Traditional Adat Community and Village: Its Characteristic and Criteria of The Adat Village}

In principle, the traditional adat community as a social system at least has 4 (four) elements namely social alignment, social standard, social media, and social control. The social alignment is expressed through a genuine social structure named "desa adat" (adat village), or other names in other regions; the social standard is expressed through ethics, traditions, etiquettes, or courtesies which keep the social life in order; the social media is languages, signs,

Hukum Progresif", makalah dipresentasikan dalam Seminar Nasional Hukum Progresif, conducted as a collaboration between the Faculty of Law of Diponegoro University and the Faculty of Law of Trisakti University December 15, 2007 at the Postgraduate Program of Diponegoro University, Semarang.

2 I Nyoman Nurjaya | [Sustainable Cultural Development...] 
codes, or symbols used as a medium of communication in the society; and the social control is expressed through a legal instrument which is established, implemented, and enforced in order to keep regularity, order, security, and peace within society.

The element distinguishing between the general society which has been known as patembayan society and that of indegenous one has its characteristics, that reflect its own philosophy, function, and specific roles in their common life in the society known as paguyuban society.

The distintive characteristics of traditional adat community as a legal entity are as follow:

1. The pattern of adat community life is familiar community (paguyuban), communal, and harmony-oriented ;

2. The way of thinking of the adat community is magic-religious, meaning that the communal society is always oriented to the equilibrium and harmony between skala (physically) and niskala (spiritually) world views;

3. Any decision making is conducted within paruman desa (village meeting) with deliberation involving all members of the village namely krama desa ;

4. Perspectives on what is patut (proper) or tidak patut (improper) priciples not true or false - becomes a common standard to value speech and behavior of the community members;

5. Every legal acts must be done in terang (open manner) with witness or before many people) and kontan/tunai (cash) so that it will be accomplished at the time of the legal acts are done;

6. The essence of sanction for breaking the indegenous legal norms is not intended to revenge, hurt, or imposing physical sanctions, but rather it is intended to imposing social and moral sanction or a sanction in terms of doing magic ritual; its purpose is to return the equilibrium of spiritual life in the village (restutitio in integerum); and the pattern of indegenous sanction is collective in nature because the doer's family are sanctioned also.

The ingenous village or other names in other regions is a genuine legal association of Indonesian having peculiar and social system and social structure, which can be identified by the following philosophy, pattern, and characteristics as follows:

1. A group of people who have many years and generations living, growing, and developing in a certain region in a certain boundaries according to their concept of boundary;

2. They become an indegenous legal community because of their common tradition, because of the unity in genealogy or territory or combine of the genealogy and territory;

3. Having a specific system of adat government include its institution of dispute settlement for the offense of adat law;

4. Having adat norms namely customary adat law in the form of written and mostly unwritten;

5. Having communal physically (skala) as well as magic property (niskala);

6. Having a peculiar religious and believe system within the life of community.

Dealing with the obove characteristics, in particular case when we observe the Balinese adat village that so called desa 
adat or desa pakraman, there is an addition criterias as follows;

7. There should be kahyangan tiga or tri kahyangan (pura desa bale agung, pura puseh, and pura dalem) within the Balinese village as an element of parhyangan according to the teaching of Tri Huta Karana;

8. There should be village market /peken desa which becomes a center of village economic activity ;

9. There should be village setra/sema for funeral ceremony (ngaben);

10. There should be village pecalang as the guard of security, keeping harmony, and order of the village;

11. There is a banyan tree (punyan bingin) as a shelter of ritual activity within the village.

2. Recognition and protection of the Traditional Adat Community: Is It Genuine Or Pseudo Recognition?

Constitutionally, the indigenous legal community has a genuine constitutional recognition as a legal entity that is equal with other citizens in national life. It has been formulated in the Explanation of Article 18 of the 1945 Constitution (the name before Amandment) which states:

"In the territory of the State of Indonesia, there is approximately

\section{Zelfbesturende landschappen} and Volksgemeenschappen as desa in Java and Bali, Nagari in Minangkabau, desa (village) and marga (clan) in Palembang, and so on. These regions have native order and therefore can be considered as a special region. The Republic of Indonesia respects the position of the special regions and all regulations regarding the special regions provides the rights of the origin of the region. Therefore, their existence still must be recognized and given assurance of continuity of life within the Unitary State of the Republic of Indonesia.".

However, there is a substantial amandment in that 1945 Constitution (Undang-Undang Dasar Negara Republik Indonesia Tahun 1945/UUD NRI Tahun 1945 named after amandment, dealing with respect and recognition of the indigenous community in national life. This is explicitely formulated in Article 18 of the 1945 Constitution becoming Article 18B Paragraph (2) that stating:

"The State recognizes and respects the unity of the indigenous legal community with all their traditional rights as long as they are still alive and in accordance with the development of society and the principles of the Unitary State of Republic of Indonesia, which is regulated in the national laws".

Dealing with that formulation, the word "as long as" within the norm of that Article confirms a particular condition limitating a recognition of the existence of indigenous community and their traditional adat rights, because the recognition will be existed as long as the condition is fulfilled, and therefore only the adat community fulfilling the offically requirements will the only be recognized by the Indonesian government. Therefore, the recognition of 
the existence or non-existence of indigenous adat community is highly dependent on the will of the ruling government. The word "as long as" has a meaning of officially restiction to the scope of life of the legal society units namely traditional adat community which de facto, they are still alive and keep on growing in the region of Indonesia.

Hence, it can be said that the respect and recognition which is normed in Article 18B Paragraph (2) of the 1945 Constitution (UUD NRI Tahun 1945) has been a pseudo constitutional recognition, because it does not recognize the indigenous adat community as a legal entity that is equal with other citizens communities. However, this kind of offically unrecognition is natutally has no meaning to the indigenous adat community which in fact is still exist, live, and develop in the sovereign territory of Indonesia. ${ }^{3}$

The norms of genuine legal recognition to the indigenous legal community as a legal entity, in the terms of not formulated in the word of "as long as" in the legal norm, can officially be found in the formulation of the Decision of People Representative Assembly the Republic of Indonesia that is Ketetapan MPR RI No. IX/MPR/2001 concerning Pembaruan Agraria dan Pengelolaan Sumber Daya Alam (Agrarian and Natural Resources Management), especially Article 4 (j) which states: "recognising, respecting, and protecting the indigenous adat communities and cultural diversity of their own natural resources". This is also explicitely regulated in Law Number 5 of 1994 concerning Ratification of the United Nations on BioDiversity; Law Number 39 of 1999 on

\footnotetext{
3 I Nyoman Nurjaya, "Adat Community Lands Right As Defined Within The State Agrarian Law of Indonesia: Is It A Genuine Or Pseudo Legal Recognition?, in the US-China Law Review Volume 8, Number 4, April 2011, David Publishing Company, Illinois, USA.
}

Human Rights; Law Number 29 regarding 1999 on the Ratification of United Nations Convention concerning the Elimination of All Forms of Racial Discrimination; Law Number 11 of 2005 on the Ratification of International Covenant on the Economic, Social, and Cultural Rights; and Law Number 12 of 2005 on the Ratification of International Covenant on the Civil and Political Rights.

Furthermore, the genuine recognition to the indigenous adat community as a legal entity is expressed through some Decisions of Indonesian Constitutional Court (Mahkamah Konstitusi), such as:

(1) The Decision of Indonesian Constitutional Court Number 010/PUU-I/2003 on the Judicial Review on the Indonesian Law Number 11 of 2003 on the Amandment of Law Number 53 of 1999 on the Establishment of Palalawan Regency, Rokan Hulu Regency, Rokan Hilir Regency, Siak Regency, Karimun Regency, Natuna Regency, Kuantan Singingi Regency, and Batam City to the 1945 Constitution;

(2) The Decision of Indonesian Constitutional Court Number 007/PUU-III/2005 on the Review of Law Number 40 of 2004 on the National Social Security to the 1945 Constitution;

(3) The Decision of Indonesian Constitutional Court Number 31/PUUV/2007 on the Review of Law Number 31 of 2007 on the Establishment of Tual City in the Province of Maluku to the 1945 Constitution;

(4) The Decision of Indonesian 
Constitutional Court Number 6/PUUVI/2008 on the Review of Law Number 51 of 1999 on the Establishment of Buol Regency, Morowali Regency, and Banggai Island to the 1945 Indonesian Constitution;

(5) The Decision of Indonesian Constitutional Court Number 3/PUUVIII on the Review of Law Number 21 of 2007 on the Management of Coastal and Small Islands to to the 1945 Constitution;

(6) The Decision of Indonesian Constitutional Court Number 21 Tahun 2001 which has been amended by the Government Regulation in Lieu of Law Number 1 of 2008 on the Special Autonomy for Papua Province to the 1945 Constitution;

(7) The Decision of Indonesian Constitutional Court Number 35/PUU$\mathrm{X} / 2012$ on the Review of the Law Number 41 of 1999 on Forestry to the 1945 Constitution; and

(8) The Decision of Indonesian Constitutional Court Number 6/PUUXI/2013 on the Review of Law Number 8 of 2012 on the General Election of the Regional Legislative Members, Regional Reperesentatives to the 1945 Constitution.

The regulations stating respect but reflect pseudo legal recognition to the rights of traditional adat communities over natural resources they depend on are explicitely formulated within a number of the Acts with regard to the management of natural resources, such as Law Number 5 of 1960 on Basic Agrarian Law; Law Number 41 of 1999 on Forestry; Law Number 7 of 2004 on Water Resources; Law Number 31 of 2004 on Fishery; Law Number 32 of

\footnotetext{
4 I Nyoman Nurjaya, "State Law in Multicultural Country of Indonesia: Toward A Just and Equitable State in Legal Anthropology Point of View", in the US-China Law Review Volume 9, Number 1, February 2012, David Publishing
}

2004 on Regional Government; Law Number Tahun 2007 on the Management of Coastal Regions and Small Islands; Law Number of 2009 on Mineral and Coal Mining.

From the historical perspective of laws that have been enacted regulating village, it can be observed an interesting development reflecting the up and down in terms of the recognition of indigenous village as volksgemeenschappen in the system of Indonesian constitutional law. In the era of the Post Indonesian Independence in 1945, the village social system is regulated in Law Number 22 of 1948 on the Principles of Regional Government; followed by the Law Number 1 of 1957 on the Principles of Regional Government; Law Number 18 of 1965 on the Regional Government; then Law Number 19 of 1965 on Praja Village As a Transitional Form to Accelerate the Establishment of the Level III Region thorough Indonesia Territory; followed by Law Number 5 of 1974 on the Principles of Regional Government ; Law Number 5 of 1979 on Village Government; law No. 32 of 2004 on Regional Government; and currently the enactment of Law Number 6 of 2014 concerning Village.

The legal politics reflected in the Law regulating Village before Law Number 5 of 1974 recognizes the existence of indigenous village as a volksgemeenschappen/selfgoverning community as well as a legal entity which has a genuine character of legal recognition. However, posterior the enactment of Law Number 5 of 1974 on Regional Government, and followed by Law Number 5 of 1979 on Village Government, which addhered legal politics of village in the form of unification and uniformity are naturally denying the cultural plurality of Indonesian, ${ }^{4}$ then the scope of life of the indigenous village is

Company, Illinois, USA. 
threatened and apparent death in mostly regions of Indonesia, except the life of indigenous adat villages in Bali Province which are still alive and co-existence with the formal and administrative villages under the structure of the Regional Government.

By enacting the Law Number 6 of 2014, which is in principle addheres legal politics of recognizing of two kinds of villages namely desa (administrative village) and desa adat (adat village), however, still there is a confusion in understanding the meaning of adat village and it is really reflected in the nuances of the denial on the philosophy and essence, function, and the main role of desa adat (adat villages) in the whole system of social and cultural life. It is in fact the mentioned Law of 2014 naturally contains the spirit, moral message, and normative will to do mixing/hybriding to coopt two forms of village which is actually different in their philosophy, function, and roles in the social system and the regional government system; in principle desa (administrative village) runs the functions of local selfgovernment, administrative government, based on the State law, whereas adat village (desa adat) run its functions as selfgeverning community which include communal and the magic-religious nuances, regulating the skala and niskala world view in the life of community which established based on the unwritten or written adat law (that so called awig-awig in Balinese adat villages).

In turn, such legal politics bring about the consequence of destructing the system of traditional adat government system as a genuine structure of the society (volksgemeenschappen) in mostly regions of Indonesia except the desa adat in Bali Province. The reasons why can be mentioned as follows: the local government to clearly make a distinction between desa adat as a selfgeverning community and desa dinas as a local self-government;

(2) Desa dinas and desa adat in Bali de facto co-exists harmoniously and play their respevtive function and roles in the daily lif of the Balinese comunities; and

(3) Desa dinas and desa adat are able to fairly play their respective fuctions and roles together in the Balinese community and Village according to their own essence based on the adat law in one hand, and on the other hand the desa dinas is based on the State law; Desa adat has functions in the field of culture, adat, and ritual tradition of Hindu religious life, whereas the desa dinas plays its function and roles in the field of birocracy in the level of official village, running adminsitrative role and becomes the part of regional government structure.

This proves that the legal plurality in the really life of society is a necessary condition and the fact, not an illusion, mitos, claim, ideal, as stated by John Griffiths as follows:

Legal pluralism is the fact. Legal centralism is a myth, an ideal, a claim, an illusion. Legal pluralism is the name of a social state of affairs and it is a characteristic which can be predicted of a social group. The ideology of legal centralism, law is and should be the law of the state, uniform for al persons, exclusive of all other law, and administered by a single set

(1) The commitment and assertiveness of 
of state institutions. ${ }^{5}$

\section{The Future of Desa Adat Posterior the Enactment of Law Number 6 Year 2014 Regarding Village}

On January 15 of 2014, the Indonesian Goverment passed and enacted Law Number 6 of 2014 regarding Village for the purpose of regulating villages, to clarify their status and provide legal certainty, recognition and respect, and empowering villages in the implementation of national development policy. The good purpose is received with open arms and positive thinking as long as it is aimed to bring the message of Paragraph IV of the 1945 Indonesian Constitution into reality, namely ".... to protect whole people of the Nation and to advance national territory and generating general welfare of the people, to educate people and to participate in providing world order based on liberty, long-life peace, and social justice."

Critically analized, that Law Number 6 of 2014 is ambiguity-nuanced dealing with the respect and the recognition of desa adat (adat villages); In one hand, it principally provides recognition to the Village which consists of both desa and desa adat, but on another hand - the General Elucidation and the Elucidation of each Articles within the Law show: (1) the suspicion of legislative body on the exixtence of indigenous village which is termed as "...... kind of village that has been oldest and democratization, causes gaps among regions, poverty, and bring social-cultural problems disturbing the Unitary State of the Republic of Indonesia"; (2) treating the desa adat as the same the formal village (desa dinas) whereas actually they have different essences, characters, functions, and roles; (3) totally intervening the system of adat village government referring to the customary law (the so called awig-awig in

\footnotetext{
5 John Griffiths, "What is Legal Pluralism", in Journal of Legal Pluralism and Unofficial Law No. 24/1986, p. 21.
}

Bali) with the state legal instruments (laws and regulations). ${ }^{6}$

The critical analysis can be initiated from the comprehension of the meaning of the legal concept of village as intended in Article 1 point 1 that stating: "The meaning of Villages is desa (administrative village) and desa adat (adat village) or to be mentioned with other terms, and for the next parts is termed as "village", is...... and so on ". The legal concept of desa (administrative village) and desa adat (adat village) is absolutely different, but it has been understood bya the Government as the same, as "the unity of legal community within certain regions having authorization to regulate and manage governmental business, the interests of local society based on the inisiatives of them, the right of genealogy, and/or traditional right recognized and respected within the governmental system of the Unitary State of the Republic of Indonesia." The proper regulation sholud recognize each of the village and define the terms reflecting the philosphy, essences, functions, and roles in the whole system of Unitary State of the Republic of Indonesia.

Article 6 Paragraph (1) explicitely states "Villages consist of desa (administrative village) and desa adat (adat village). It is an expression of de yure recognition to the 2 (two) types of village in the government system of the Unitary State of Indonesia, giving them a co-existence life space in playing repective function and roles in the village government. However, the norm in Article 6 Paragraph (1) would be ambigue and inconsistence when it is explained in the Elucidation of that Article which stating:

This provision is intended to prevent the intersection in regions, authority, institutional duplication between Desa and Desa Adat within the same region. It is,

\footnotetext{
${ }^{6}$ Read and criticize the General Elucidation and the Elucidation of Article 6 of Law Number 6 of 2014 on Village.
} 
therefore, in one region sholud be the only 1 (one) Desa or Desa Adat. In order to do that, it must be chosen one type of village according to provision of this Law.

According to the statutory law, an Article is a legal norm that is legally binding, whereas the Elucidation is not a legal norm, it is only statements to make the meaning and the intention more clearly and understandable. Its legal implication is, there is no sanction in case the Elucidation of Article 6 is not obeyed and or not implemented.

The provision in the Articles of Law Number 6 Year 2014 on Village has been loaded with legal norms that intervening the autonomy and the existence of desa adat which has peculiar essences, functions, and roles comparing with the administrative village which based on the State law. Hence, it can be concluded from the provisions that intervening the institutional system of indigenous village, the election mechanism of the head of the village as well as the tenure of office, the making of indigenous village regulation, the forming, unifying, and dissoluting of the village, as well as the regulation of indigenous village's physical and magic property (the assets desa adat nuanced as skala and niskala), because the traditional adat village is identified the totally same as desa dinas (administrative village) according to the regional government in the level of village.

This is really impossible to do, because the legal consequences of the anctment of Act Number 6 of 2014 is that the existence of traditional adat community include of its adat law in the whole regions of Indonesia, as well as desa adat and its awig-awig especially in Bali), finally in the time of slowly but sure would be perished and determinated from the social and cultural system in the multicultural country of Indonesia, except in Aceh, Papua, and West Papua. ${ }^{7}$

\section{CONCLUSION}

From ancient days until the recently time, Bali keeps on guarding and continuing the inheritance of its social and culture and religious community system that created by the Balinese Ancestors, and it is expressed in the form of desa adat/desa pakraman include its customary law named awig-awig as an instrument of social and cultural supervision and control in the daily life of Balinese adat community that imbued and furnished by Hindu religion precepts.

Orientation and regulation of the Village Government as formulated in the Act Number 6 of 2014 concerning Villages as well as the Government Regulation Number 43 of 2014 on the Implementative Regulation of Law Number 6 of 2014 has naturally been bureucratic and offical law that regulated village within system of the regional government under the supervision of the State law. Hence, it is really not wise if the Government was about to impose the enforcement of State laws against adat villages namely desa adat/desa pakraman as a legal entity of the genuine character of traditional adat community. It is because the desa adat which is based on customary adat law has its own systems, philosophy, functions, and roles in both skala and niskala spheres and world view, and they are distinctive in nature, so that they cannot be enforced and treated as the same as desa dinas in the administrative structure of the regional government.

The provisions to understand the clearly meaning substances of the norms within the Act Number 6 Tahun 2014 on

\footnotetext{
${ }^{7}$ Read the Specific Provision of the General Elucidation Point 13 of Law Number 6 of 2014 on Village.
} 
Village, shows that the life space of adat village is naturally still recognized legally with the reasons as follows: (1) The Elucidation of Article 6 is not a norm legally binding and therefore it must be neglected and ignored as a legal norm; (2) Article 116 Paragraph (1) explicitely states: "The villages which have been existed before this Law would be recognied as a Village "; and Paragraph (2) states : "The Regional Government and Regency/Municipality provides the Local Regulation on the desa (administrative village) and desa adat (adat village) in their respective region.". ${ }^{8}$

What could be mentioned from the above legal norms is the Article 116 Paragraph (1) confirms that both desa and desa adat is clearly recognized as Desa. De facto, the desa adat is in the empirical condition still alive and grow coexistently together with the desa dinas (administrative village), and there is no intersection between the two kind of villages. In fact, both of them live in each own way with their respective functions and roles according to their essence in the time of national development implementation, a long time before the enactment Law Number 6 of 2014 on Village.

It can, therefore, be concluded that in principally, the Law Number 6 of 2014 regarding Village provides legally recognition and protection to the existence of desa adat (traditional adat village) in line with its philosophy, essences, functions, and roles within the whole system of unitary adat community under the supervision on its customary adat law, which is in reallity sustained living and growing together in the co-existence condition with the desa dinas (administrative village) in conducting the bureucratic function and role of the regional governmental administrative system which based on the State law.

In the sense of Explanation Article 6 Act Number 6 Year 2014 that stating: "This provision is intended to prevent the intersection in regions in term of authority, institutional duplication between Desa and Desa Adat within the same region. It is, therefore, in one region should be the only 1 (one) Desa or Desa Adat. In order to do that, it must be chosen one type of village according to provision of this Law", I should say that it has not been a really norm of the legislation that has binding power to be implemented. In contradiction, in case the Balinese and the Bali regional government as well is intended to chose the desa adat/desa pakraman to be registered with the hope to the only receive a village financial empowerment every year from the Government, I should personally advice that there will be a number of legal consequences with the fate and future of existence and the life of desa adat/desa pakraman as a social and cultural system of Balinese Hindu community in particular and the whole traditional adat communities in the multicultural country of Indonesia in general. Why? The only reasons are as follows:

1. Legal based of the development desa adat/desa pakraman will not remain be an awig-awig as customary law of Balinese traditional community which regalutes skala and niskala world view and spheres in the daily life of the community rather it enforce and must be under the supervision of the Act Number 6 Year 2014 regarding Village and its implemented regulations namely the State law;

2. It means that philosophy and essence, function and the role of desa adat/desa pakraman absolutly change in physically as well as terminate and perish in reallity within the life Balinese community;

\footnotetext{
${ }^{8}$ Village refers to both Desa (administrative village) and Desa Adat (adat village) as it is meant in the Article 1 Point 1 of the Act Number 6 of 2014 on Village.
} 
3. Traditional adat government structure and governance system should be change in accordance with the governance system of desa dinas (administrative village); in one side desa adat/desa pakraman should govern the administratice and bureucratic affairs under the structure of regional government, and on the other side the desa adat is at the same time in charge to govern and responsible about cultural, adat tradition and rituals as well as Hindu religion affairs;

4. It meas that nuance of the skala and niskala spheres and world view of the desa adat/desa pakraman should totally be ignored in the daily life of Balinese village and community;

5. In relation to governance system of desa adat/desa pakraman, in term of adat government structure in particular, village officials (prajuru desa) election and time of duty mechanism, as well as legal status of village property that has skala (physically) and niskala (magisch, spiritually, and religious) nuances and values in the eyes of Hindu Balinese community should become the physically property ownership of the regional government;

6. Village officials (prajuru desa) should officially be responsible and liabel for the use of village financial empowerment that given by the regional government in the form of official financial report every year as administrative village legal obligation. In case of corruption conducted by the desa adat officials (prajuru desa) that will absolutly be qualified as a crime in accordance to criminal law.

DAFTAR PUSTAKA
Griffiths, John, "What is Legal Pluralism", dalam Journal of Legal Pluralism and Unofficial Law No. 24/1986, p. 21.

Nurjaya, I Nyoman, Pengelolaan Sumber Daya Alam dalam Perspektif Antropologi Hukum, Prestasi Pustaka Publisher, Jakarta, 2008.

Nurjaya, I Nyoman, "Reorientasi Paradigma Pembangunan Hukum Nasional dalam Masyarakat MultiKultural: Perspektif Hukum Progresif", makalah dipresentasikan dalam Seminar Nasional Hukum Progresif I diselenggarakan atas kerjasama Fakultas Hukum Universitas Diponegoro dan Fakultas Hukum Universitas Trisakti pada tanggal 15 Desember 2007 di Program Pascasarjana Universitas Diponegoro, Semarang.

Nurjaya, I Nyoman, "Adat Community Lands Right As Defined Within The State Agrarian Law of Indonesia: Is It A Genuine Or Pseudo Legal Recognition?, dalam the US-China Law Review Volume 8, Number 4, April 2011, David Publishing Company, Illinois, USA.

Nurjaya, I Nyoman, "State Law in Multicultural Country of Indonesia: Toward A Just and Equitable State in Legal Anthropology Point of View", dalam the US-China Law Review Volume 9, Number 1, Febroary 2012, David Publishing Company, Illinois, USA.

Undang-Undang Dasar 1945 (nama UUD sebelum Perubahan) 
Undang-Undang Dasar Negara Republik Indonesia Tahun 1945 (nama UUD setelah Perubahan)

Undang-Undang Republik Indonesia Nomor 32 Tahun 2004 tentang Pemerintahan Daerah

Undang-undang Republik Indonesia Nomor 6 Tahun 2014 tentang Desa

Putusan Mahkamah Konstitusi Nomor 010/PUU-I/2003 perihal Pengujian Undang-Undang Republik Indonesia No. 11 Tahun 2003 tentang Perubahan Atas UU No. 53 Tahun 1999 tentang Pembentukan Kabupaten Palalawan, Kabupaten Rokan Hulu, Kabupaten Rokan Hilir, Kabupaten Siak, Kabupaten Karimun, Kabupaten Natuna, Kabupaten Kuantan Singingi, dan Kota Batam terhadap UndangUndang Dasar Negara Republik Indonesia 1945;

Putusan Mahkamah Konstitusi Nomor 007/PUU-III/2005 perihl Pengujian Undang-Undang Nomor 40 Tahun 2004 tentang Sistem Jaminan Sosial Nasional terhadap Undang-Undang Dasar Negara Republik Indonesia 1945;

Putusan Mahkamah Konstitusi Nomor 31/PUU-V/2007 perihal Pengujian Undang-Undang Nomor 31 Tahun 2007 tentang Pembentukan Kota Tual di Provinsi Maluku terhadap Undang-Undang Dasar Negara Republik Indonesia 1945;

Putusan Mahkamah Konstitusi Nomor 6/PUU-VI/2008 perihal Pengujian Undang-Undang Nomor 51 Tahun 1999 tentang Pembentukan Kabupaten Buol, Kabupaten Morowali, dan Kabupaten Banggai Kepulauan terhadap UndangUndang Dasar Negara Republik Indonesia 1945;

Putusan Mahkamah Konstitusi Nomor 3/PUU-VIII perihal Pengujian Undang-undang Nomor 21 Tahun 2007 tentang Pengelolaan Pesisir dan Pulau-pulau Kecil terhadap Undang-Undang Dasar Negara Republik Indonesia 1945;

Putusan Mahkamah Konstitusi Nomor 21 Tahun 2001 yang telah diubah dengan Peraturan Pemerintah Pengganti Undang-Undang Nomor 1 Tahun 2008 tentang Otonomi Khusus Bagi Provinsi Papua terhadap Undang-Undang Dasar Negara Republik Indonesia 1945;

Putusan Mahkamah Konstitusi Nomor 35/PUU-X/2012 tentang Pengujian Undang-Undang Nomor 41 Tahun 1999 tentang Kehuatanan terhadap Undang-Undang Dasar Negara Republik Indonesia 1945; dan

Putusan Mahkamah Konstitusi Nomor 6/PUU-XI/2013 perihal Pengujian Undang-Undang Nomor 8 Tahun 2012 tentang Pemilihan Umum Anggota Dewan Perwakilan Rakyat, Dewan Perwakilan Daerah, dan Dewan Perwakilan Rakyat Daerah terhadap Undang-Undang Dasar Negara Republik Indonesia 1945. 